\title{
薄板材料のプレス成形における成形限界の予測と 加工硬化特性の影響
}

\author{
顧 莉薇* ·田中 昭徳 ${ }^{* 2} \cdot$ 田中 研治*3 . 中島 浩衛*4 \\ Prediction of Forming Limit Diagram (FLD) and Effect of Work Hardening Property on FLD of Sheet Metals \\ Liwe $i$ Gu, Akinori Tanaka, Kenji Tanaka and Koe Nakajima
}

\begin{abstract}
Synopsis : The necking limit diagram NLD and the forming limit diagram FLD under the wide-range bi-axial tensile stress conditions were obtained by using various sheet metals of steels, Al-alloys and a copper. The good correlation between the limited strain values of NLD and FLD and the mechanical properties of total elongation and $r$-value etc. were obtained. Moreover, the strain dependency of the work hardening coefficient $n$-value in higher strain area was different according to each material. The complex value of $n$-value and $r$-value was defined as the equivalent work hardening coefficient $n_{\mathrm{eq}}$-value in higher strain area. And when the $n_{\mathrm{eq}}$-value was substituted to Gotoh's modeling of localized necking limited strain, FLD that accuracy is high was able to be predicted.
\end{abstract}

Key words : necking limit diagram; forming limit diagram; mechanical property; $r$-value; $n$-value; equivalent work hardening coefficient; FLD prediction.

\section{1. 緒言}

薄板材料のプレス成形における成形不良現象には, 各種 形態の破断および面形状性としてのしわやひけなど，さら に寸法精度を支配するスプリングバックなどのさまざまな ものがある。それらのなかでも破断としわなどの不良現象 の発生は, プレス成形過程で一つの成形品の中に共存して いる典型的な不良現象であるとされている。とくに，成形 品の破断・われなどは, 成形工程の最終的段階で修正がで きないため，各種材料に対してこれらの不良現象が生じな い成形可能な限界範囲を, あらかじめ明確に把握しておく 必要がある。

一般に, 薄板成形の成形限界に至るまでの変形には，お よそ次の 4 つの段階があるとされている1。すすおち, 成 形がほぼ一様に変形する第 1 段階, 次いで特定の部分の変 形が最大となるような不均一変形（変形の局所化）の第 2 段階, さらに変形が進み，一部が他よりも薄くなる局所く びれ变形の第3段階, さらに負荷が増大すると, 局所くび れの狭い領域に板厚方向にわたってせん断ひずみが集中し 破断に至る第4段階がある。このように，それまでの変形 様式から違った変形様式へと変わっていく現象が, いわゆ る分岐現象である。第3段階の分岐が局所くびれ限界 (Localized Necking Limit Diagram, 以下NLDと略称) に相 当し，この局所くびれが発生すると，それ以降はこの部分
に变形が限定されて第4段階の分岐の破断による成形限界 (Forming Limit Diagram, 以下FLD と略称）に至る。

薄板材料のプレス成形過程に打ける $\mathrm{FLD}^{2 \sim 71}$ は，広範な 2 軸応力条件下で破断部の最大ひずみと最小ひずみを成形限 界值とする線図によって表され，データベースも蓄積され つつある。また, 成形限界線図を求める試験法に関しても， 国際的に共通の試験法 ${ }^{2}$ が検討されている。また，FLDへ の Stören-Riceの局部くびれ理論 ${ }^{8)}$ (以下 S-R理論と略称) の適用研究が行われており，〈びれ現象を別の観点からみ ると, 板表面の肌荒机現象 ${ }^{5,6)}$ や板厚の不整（局部くぼみ） 現象 ${ }^{9,10)}$ が，破断の前兆現象として観察されている。

S-R 理論 ${ }^{81}$ は, Hillの理論 ${ }^{(4)}$ を拡張して, 第3段階の分岐 すなわち局所くびれの発生をもって，FLDを評価している すなわち，材料の局所くびれの発生を破断発生のきっかけ となる前兆現象として位置づけ，局所くびれの発生条件に よってFLDを予測することになる。そこで，破断の前兆 現象としての局所くびれが発生してから破断に至るまでの 変形量が問題となるので, 本研究では, 局所くびれの発生 点の定量化を行って局所くびれ発生の分岐理論の FLDへ の適応性とその評価に関する研究を行った。

本研究では, 各種の薄板材料として高張力鋼板を含めた 薄鋼板，各種アルミニウム合金薄板および銅薄板を用いて NLD およびFLDを求め，また，各種材料の高ひずみ領域 における加工硬化指数 $n$ 值を求めて, NLDおよびFLDを

平成 13 年 3 月 26 日受付 平成 13 年 11 月 14 日受理 (Received on Mar. 26, 2001; Accepted on Nov. 14, 2001)

* 大问工業大学大学院生（現：コンドーセイコー（株)）(Graduate Student, Daido Institute of Technology, now Kondo Seiko Co., Ltd.)

*2大间工.業大学大学院生（現：イズミ工業 (株)) (Graduate Student, Daido Institute of Technology, now Izumi Kogyo Co., Ltd.)

*3 大间正業大学大学院生 (現：(株) 青山製作所) (Graduate Student, Daido Institute of Technology, now Aoyama Co., Ltd.)

*4 大同 I: 業大学 (Daido Institute of Technology, 10-3 Takiharu-cho Minami-ku Nagoya 457-8530) 
支配している材料特性要因を明らかにする。さらに，局所 くびれ限界理論 ${ }^{12,13)}$ を基本とした後藤のFLDの予測式を用 いて，FLDへの適合性と予測值の精度評価を行う。

\section{2. 供試材および実験方法}

\section{$2 \cdot 1$ 供試材料}

供試材料として, 板厚 $0.8 \mathrm{~mm}$ および $1.0 \mathrm{~mm}$ の軟鋼板 (SPCC, SPCE), 高張力鋼板(SPFC), アルミニウム合金薄板 (A1100, A5000系(a, b , c)，A6000系）打よび銅薄板の合計 9 種類を用いて，FLDを求める成形実験を行った。供試材の 機械的性質の平均值を Table 1 に示す。

\section{$2 \cdot 2$ 成形限界実験方法}

成形限界線図 FLDを求める試験法として，Fig. 1 に示す “Nakajima’s Specimen”法の球頭ポンチ型成形試験を行った。 試験片として圧延方向に採取した幅W12.5 125 mm (12.5, $30,40,60,80,92,100,108,120) \times$ 長さ $165 \mathrm{~mm}, 125 \times 125$ $\mathrm{mm}$ の 10 種類を使用した。また, 成形限界試験はダイス直 径 $82 \phi \mathrm{mm}$ ，ポンチ直径 $80 \phi \mathrm{mm}$ であり，ブランクの拘束条 件としては，ビード付きダイス（ビード直徍 $102 \phi \mathrm{mm} ）$ を 用いて，ブランク押さえ力を $58.8 \mathrm{kN}$ (6 ton)一定にて行っ た。潤滑油は，工作油；620を用い，ポンチ表面に塗布し て実験を行った。また，等 2 軸張出し成形の場合のみ同潤 滑油\#660-1 とポリエチレンシートを併用して行った。

成形後のひずみの測定は，成形前の試験片にあらかじめ スクライブドサークル (半径の $1 / 2$ シフトした直径 $5 \phi \mathrm{mm}$ の複合サークル）を専用インクで刻印し, 成形後セロテー プに転写して最大ひずみ $\varepsilon_{x}$ と最小ひずみ $\varepsilon_{y}$ の測定を行っ

Table 1. Mechanical properties of used materials.

\begin{tabular}{|l|c|c|c|c|c|c|c|}
\hline materials & $\begin{array}{c}t \\
{[m m]}\end{array}$ & $\begin{array}{c}\text { Y.P. } \\
{[\text { MPa] }}\end{array}$ & $\begin{array}{c}\text { T.S. } \\
\text { [MPa] }\end{array}$ & $\begin{array}{c}\text { T.El } \\
{[\%]}\end{array}$ & $\begin{array}{c}\bar{n} \\
\text { value }\end{array}$ & $\begin{array}{c}\bar{r} \\
\text { value }\end{array}$ & $\begin{array}{c}\bar{L} \\
\text { value }\end{array}$ \\
\hline SPCC & 0.80 & 204 & 329 & 36 & 0.217 & 1.39 & 0.126 \\
\hline SPCE & 0.80 & 146 & 275 & 46 & 0.259 & 1.87 & 0.168 \\
\hline SPFC & 0.80 & 232 & 370 & 34 & 0.215 & 1.46 & 0.128 \\
\hline A1100 & 1.00 & 60 & 99 & 35 & 0.200 & 0.59 & 0.074 \\
\hline A5000(a) & 0.80 & 122 & 284 & 33 & 0.338 & 0.69 & 0.138 \\
\hline A5000(b) & 1.00 & 117 & 276 & 30 & 0.322 & 0.73 & 0.136 \\
\hline A5000(c) & 0.80 & 116 & 265 & 29 & 0.304 & 0.94 & 0.147 \\
\hline A6000 & 1.00 & 151 & 260 & 26 & 0.225 & 0.54 & 0.079 \\
\hline $\mathrm{Cu}$ & 0.84 & 153 & 227 & 42 & 0.185 & 1.04 & 0.094 \\
\hline
\end{tabular}

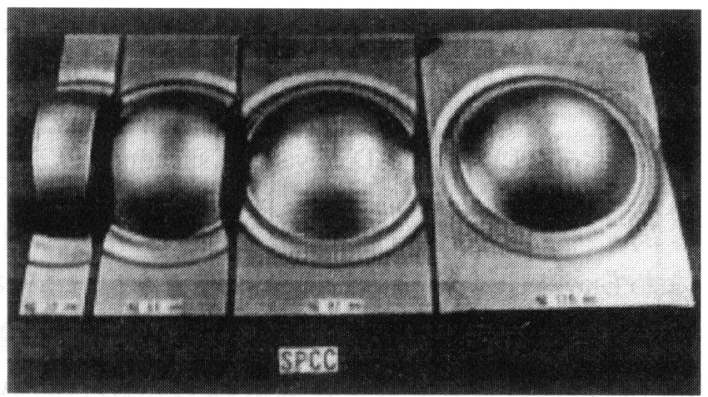

Fig. 1. Testing method for forming limit diagram.
た。破断が発生した部分は，ほぼいずれかのサークルに入 るので，転写法でひずみを測定するとき，破断による開口 部を差し引いた長さを変化量とした。

\section{$2 \cdot 3$ 高ひずみ領域の加工硬化指数 $n$ 值の測定方法}

薄板の引張り試験による加工硬化指数 $n$ 值を求める方法 は，最大荷重点までの均一伸び変形領域内で求めるのが一 般的である。しかしながら，荷重不安定点を超えた高ひず 夕領域までの加工硬化指数 $n$ 值を求める方法として, 次の ような方法を工夫して行った。すなわち, Fig. 2 に示すよ うに，あらかじめ $2 \mathrm{~mm}$ 間隔の格子を電解腐食によりマー キングした試験片を用いて引張り試験を行った。最大荷重 点までは通常の方法で引張り試験を行い，荷重不安定点以 降は，8段階程度に途中止めしながら，荷重とひずみの測 定を行うことによって $n$ 值を求めた。ただし, 途中止め試 験であるため，弾性変形量の修正を行った。

\section{3. 実験結果と考察}

\section{$3 \cdot 1$ くびれ限界および成形限界と材料特性との関係}

$3 \cdot 1 \cdot 1$ くびれ限界線図と破断による成形限界線図

(1) 変形経路と FLD

成形限界試験に打いて，最初に破断限界值を求めて FLD を得た後, 再度他の試験片を用いて, 途中止めしつつ破断 に至るまで成形過程における最大ひずみ $\varepsilon_{x}$, 最小ひずみ $\varepsilon_{y}$ の測定を行って変形経路を求めた。測定值を成形限界線四 上にプロットして求められるFLDとそれに至る変形経路 の測定例を Fig. 3 に示す。本実験の場合, 変形経路はほぼ 直線的な変形経路となっていることを示している。㛜密に は, $\varepsilon_{x} \geqq 0, \varepsilon_{y} \leqq 0$ の変形領域（一方が縮み変形を伴う領域 および平面ひずみ条件の領域）では直線的な変形経路であ り, $\varepsilon_{x}>0, \varepsilon_{y}>0$ の変形領域（張出し変形領域）では, 途 中までは直線的変形経路であるが, 変形終了域近傍で近似 的に平面ひずみ条件となっていることが観察された。

(2) 局所くびれの測定值と NLD

成形限界試験において，局所くびれが発生する点を求め るため次のように測定を行った。全体成形性を表す指標と して, 成形プロフィール全体の平均伸びひずみ $\varepsilon_{\mathrm{av}}$ と, や

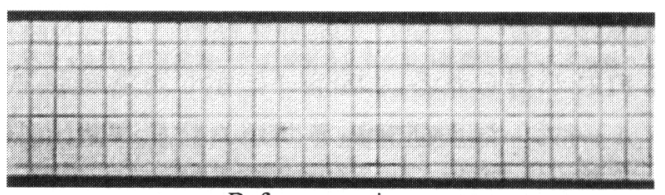

Before experiment

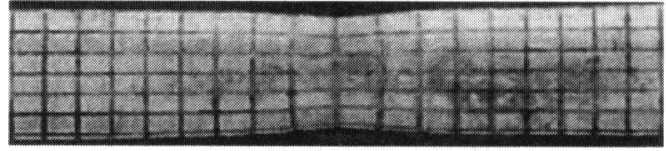

After experiment

Fig. 2. Specimen of tensile testing for work hardening coefficient $n$ value in higher strain area. 


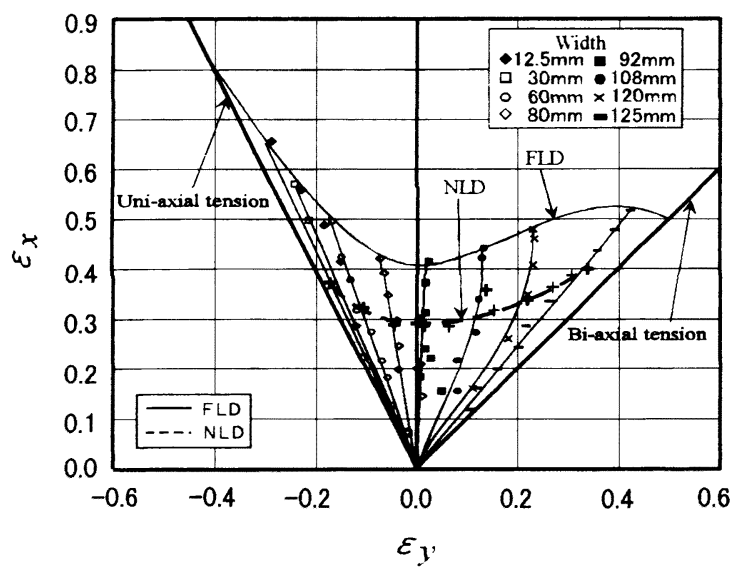

Fig. 3. Deformation path and NLD in FLD of steel sheet (SPCC).

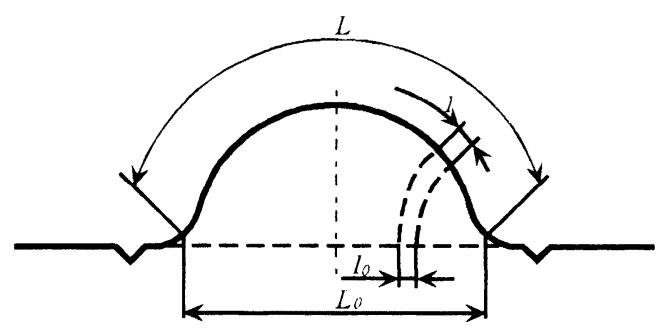

average strain : $\varepsilon_{a v}=\ln \left(\frac{L}{L_{0}}\right)$, localized strain : $\varepsilon_{x}=\ln \left(\frac{l}{I_{0}}\right)$

Fig. 4. Definition of average strain and localized strain in forming test.

がて破断が発生する局所のひずみ $\varepsilon_{x}$ の関係から, 局所に変 形の集中が開始する点を局所くびれの発生点と考えた。す なわち, Fig. 4に示すひずみの定義に従って，成形過程で 途中止めしながら求めた。このときの平均ひずみ測定の基 準寸法 $L_{0}$ は $80.5 \mathrm{~mm}$, 局部伸びひずみのゲージ $l_{0}$ はサーク ル径 $5 \phi \mathrm{mm}$ を使用した。成形試験片の幅 $W$ が $30 \mathrm{~mm}$ の場 合の $\varepsilon_{x}$ と $\varepsilon_{\mathrm{av}}$ との関係から(Fig. 5), 成形過程において局所 ひずみ $\varepsilon_{x}$ が急激に増加する点が認められ，この折れ点を局 所くびれの発生点と定義した。これらの測定結果から，局 所くびれ点のひずみNLDを, Fig. 3の変形経路と FLDの関 係図に併せて示した。

\section{( 3 ) 局所くびれによるNLDと破断によるFLD}

成形限界試験によって，局所くびれによるNLDと破断 によるFLDが得られる。Table 1に示した各種供試材の薄 鋼板グループ，およびアルミニウム合金薄板と銅薄板グ ループの両者に分けて, FLDとNLDをFig. 6に示した。

各種材料の種別間で明瞭なFLDの差が現れており，厳 密には3つの変形領域,すなわち, (1) $\varepsilon_{y}<0$ の領域（縮み変 形を伴う領域），(2) $\varepsilon_{y}=0$ の領域（平面ひずみ領域），(3) $\varepsilon_{y}>0$ の領域（2軸張出し領域）のようにに分けて考察すべ きであるが，ここではとくに(2)の平面ひずみ条件の領域に おけるFLDの傾向について述べる。

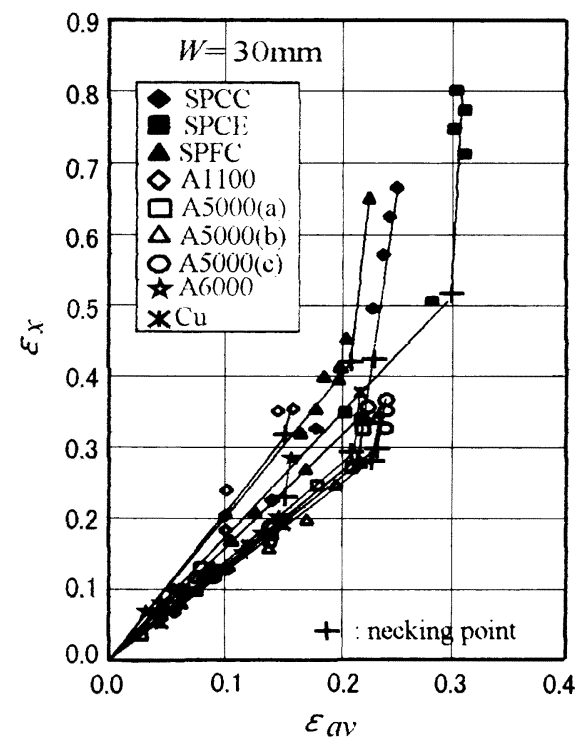

Fig. 5. Necking deformation in FLD testing with specimen width of $30 \mathrm{~mm}$.

(a) Stcel sheets

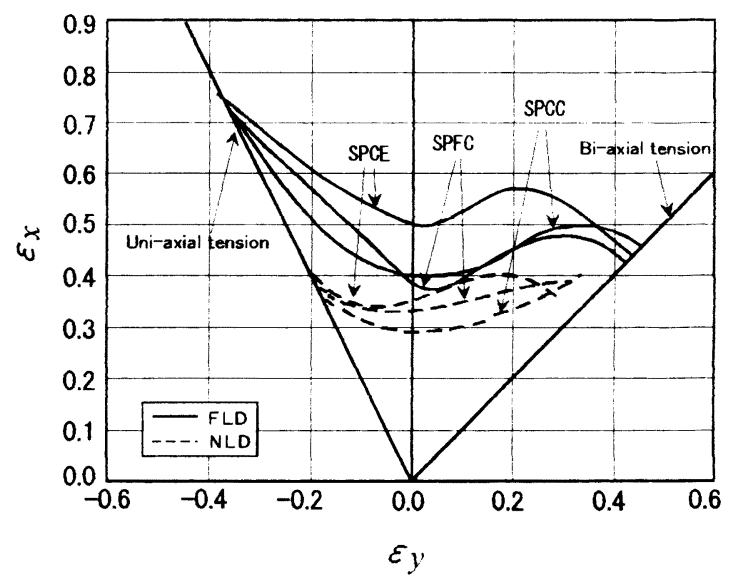

(b) $\mathrm{Al}$ alloy sheets and $\mathrm{Cu}$ sheet

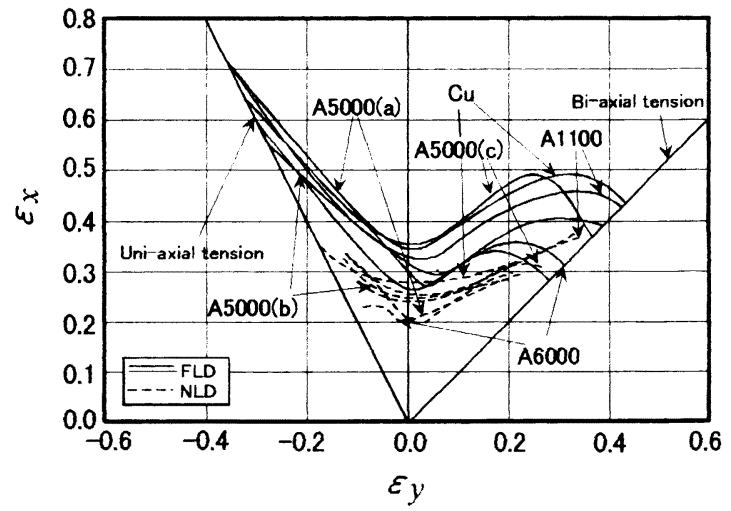

Fig. 6. FLD and NLD of various sheet metals.

すなわち，SPCE材が突出して高いFLD值を示しており， 次いで SPCC材, SPFC材となっている。薄鋼板材に次い で銅薄板材，アルミニウム合金薄板材（A1100>A5000 系>A6000系）の順となっている。ここで，アルミニウム 
(a) Effect of $\bar{n}$ value

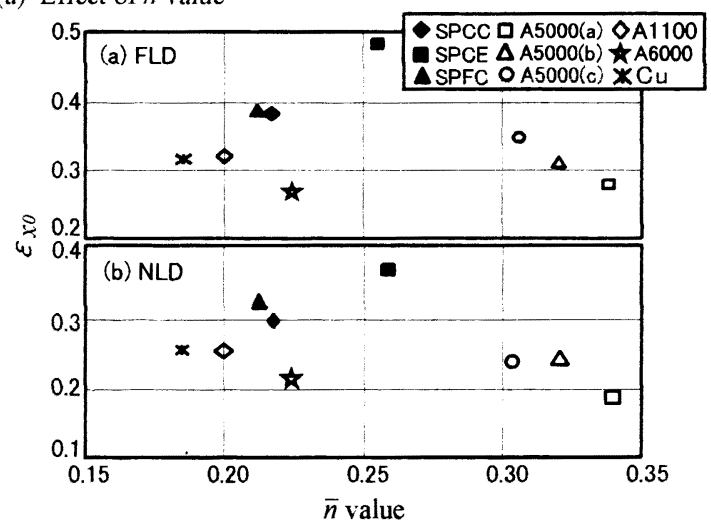

(b) Effect of $\bar{r}$ value

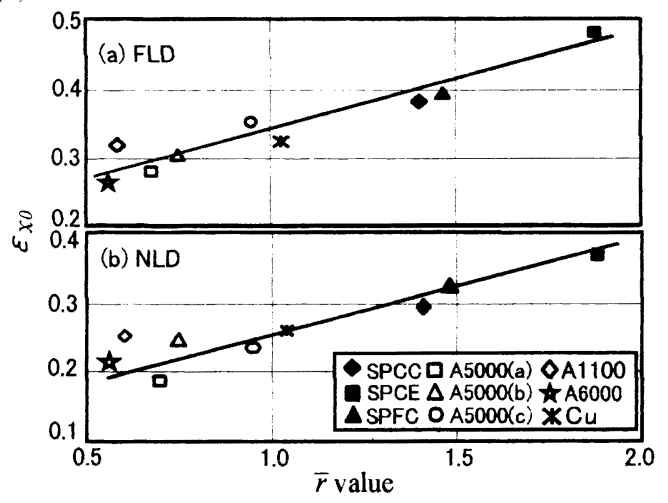

Fig. 7. Effect of $\bar{n}$ value and $\bar{r}$ value on the strain $\varepsilon_{x 0}$ in FLD and NLD.

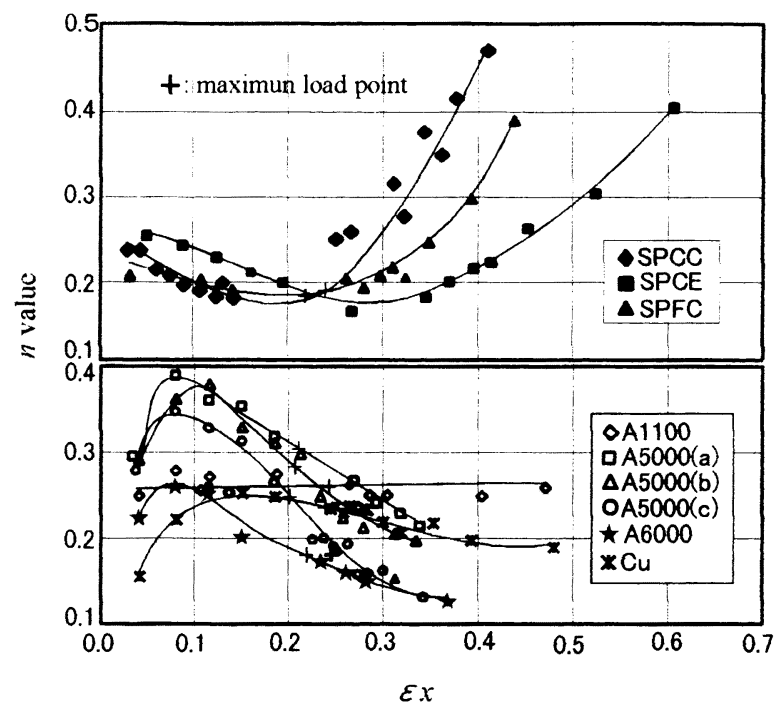

Fig. 8. Strain dependency of coefficient of work-hardening $\bar{n}$ values.

合金薄板材のなかで $r$ 值が比較的高い A 5000 系 $(\mathrm{C})$ 材 $(\bar{r}=$ 0.94)が銅薄板材と同等以上の FLD となっていることが注

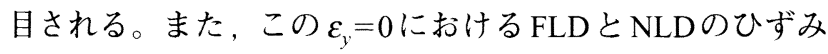
$\varepsilon_{x 0}$ 值の範囲は, 薄鋼板グループでは約 $0.37 \sim 0.50$ および約 0.30 0.37, アルミニゥム合金打よび銅薄板グループでは 約 $0.26 \sim 0.36$ および約 $0.20 \sim 0.28$ の範囲であった。
Table 2. Various $n$ values of used materials.

\begin{tabular}{|l|c|c|c|c|}
\hline materials & $\bar{n}$ value & $n^{*}$ value & $n_{c v^{*} \text { value }}$ & $n_{f}{ }^{*}$ value \\
\hline SPCC & 0.217 & 0.183 & 0.337 & 0.476 \\
\hline SPCE & 0.259 & 0.178 & 0.248 & 0.408 \\
\hline SPFC & 0.215 & 0.185 & 0.241 & 0.391 \\
\hline A 1100 & 0.200 & 0.263 & 0.250 & 0.263 \\
\hline A5000(a) & 0.338 & 0.301 & 0.250 & 0.212 \\
\hline$A 5000(b)$ & 0.322 & 0.288 & 0.229 & 0.190 \\
\hline$A 5000(c)$ & 0.304 & 0.250 & 0.179 & 0.128 \\
\hline A6000 & 0.225 & 0.188 & 0.157 & 0.137 \\
\hline Cu & 0.185 & 0.239 & 0.220 & 0.189 \\
\hline
\end{tabular}

\section{$3 \cdot 1 \cdot 2$ FLDおよびNLD と材料特性との関係}

$\varepsilon_{y}=0$ の平面ひずみ条件における FLD およびNLDのひず み $\varepsilon_{x 0}$ 值と材料特性との関係について調査を行った。材料 特性値として, YP, TS, TEL, $\bar{n}$ 值, $\bar{r}$ 値, $\bar{U}\{=\bar{n} \bar{r} /(1+\bar{r})\}$ 值 などと FLD およびNLDのひずみ $\varepsilon_{x 0}$ 值との相関関係を求め ると TEL, $\bar{r}$ 值， $\bar{U}$ 值との間に相関関係が得られた。Fig. 7 に值および值と FLDおよびNLDとの関係を示すよう に， $\bar{r}$ 值との間には非常に良い相関関係が認められるが， $\bar{n}$ 值との間には全く相関関係が得られなかった。本来，局 所くびれを破断の前兆現象とするNLDおよびFLDは， と密接な関係があることが予想されるが，鋼材，アルミニ ウム合金材および銅材などの異種材料にもかかわらず，と くに值との間に非常に良い相関関係があることは注目さ れる。

\section{$3 \cdot 2$ 高ひずみ領域における加工硬化特性值と限界ひずみ との関係 ${ }^{11)}$}

\section{$3 \cdot 2 \cdot 1$ 材料の種別による変形に伴う $n$ 值特性}

最大荷重点以降の高ひずみ領域における $n$ 值の測定を 行った結果をFig. 8に示した。薄鋼板材グループ（体心立 方格子系）とアルミニウム合金薄板材および銅薄板材グ ループ（面心立方格子系）によって， $n$ 值のひずみ依存性 の傾向が全く異なっている。

薄鋼板材グループの $n$ 值は, 最大荷重点まではひずみの 增加とともに若干低下するが，最大荷重点を過ぎるとひず みの増加とともに急激に増大し，鋼種によってその増加傾 向が異なっている。アルミニウム合金薄板材および銅薄板 材の $n$ 值は，低ひずみの変形段階では，ひずみの増加とと もにやや増加傾向がみられるが，それを過ぎるとひずみの 增加とともに単調に低下し，最大荷重点を過ぎても減少傾 向にある。ただし, $\mathrm{A} 1100$ 系のアルミニウム薄板材の $n$ 値 は，全ひずみ領域でほぼ一定であった。

\section{$3 \cdot 2 \cdot 2$ 各変形領域における $n$ 値の表示}

そこで，これらの高ひずみ領域における $n$ 值を，それぞ れ最大荷重点で $n^{*}$ 值, 最大荷重点以上の高ひずみ領域の 平均值を $n_{\mathrm{av}}^{*}$ 值および破断近傍の $n_{f}^{*}$ 值として区別した。こ れらの高ひずみ領域の加工硬化指数を，通常の $n$ 值と比較 してTable 2に示す。

ここで，実験で得られた平面ひずみ条件における NLD およびFLDの限界ひずみ $\varepsilon_{x 0}$ 值と高ひずみ領域の加工硬化 
(a) Effect of $n_{f}^{*}$ value

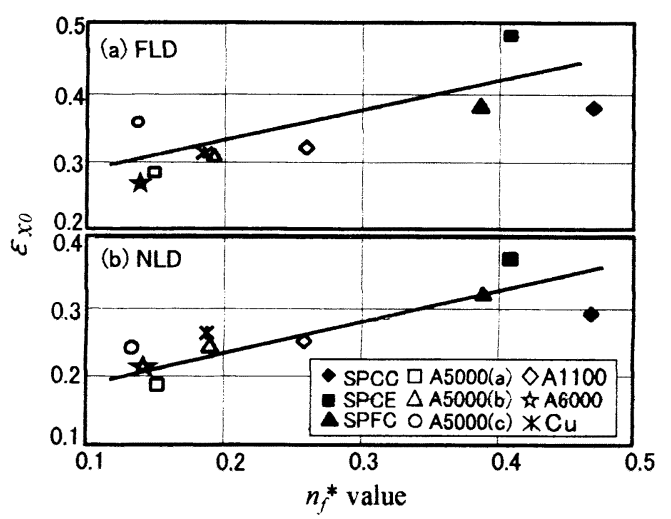

(b) Effect of $U_{f}^{*}$ value

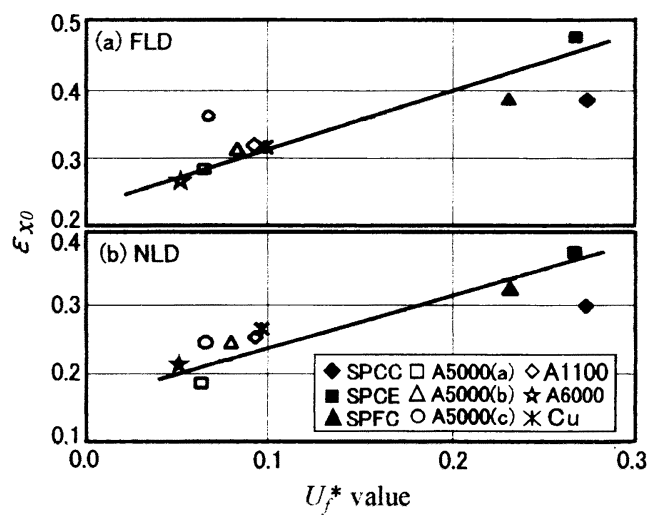

Fig. 9. Relationship between FLD strain $\varepsilon_{x 0}$ and $n_{f}{ }^{*}$ value and $U_{f}^{*}$ value.

指数の $n^{*}$ 值, $n_{\mathrm{av}}$ 值および $n_{f}$ *值などとの間の相関関係につ いて整理した。 $\varepsilon_{x 0}$ 值と $n^{*}$ 値， $n_{\mathrm{av}}^{*}$ 值との間には相関関係は 認められなかった。しかしながら，Fig. 9に示すように， 破断近傍の $n$ 值である $n_{f}^{*}$ 值および $n$ 值と $r$ 值の複合特性値 である $U_{f}^{*}\left(=n_{f}^{*} \bar{r} /(1+\bar{r})\right)$ との間に比較的良い相関関係が認 められた。

\section{$3 \cdot 2 \cdot 3$ 高ひずみ領域の $n$ 值特性について材料面からの考 察}

Fig. 8に示すように, 薄鋼板材グループとアルミニウム 合金薄板材および銅薄板材グループの種別によって，変形 の進行に伴う $n$ 值の変化特性が著しく異なる点について, 材料面からの若干の考察を行った。一般に，引張り試験に おいて, 変形量の増加に伴って材料の強度が増加するが, 真ひずみの増分に対する真応力の増分比が加工硬化指数 $n$ 值である。最大荷重点までの均一伸び変形領域内において も，微視的には変形が均一に進行するのではなく，材料内 部の軟質の箇所や，形状的に応力が集中する場所が優先的 に変形するが，一般に変形した個所は加工硬化して転位が 動きにくくなるため，次の変形は硬化した領域の隣接する 場所に起こる。

最大荷重点までは, 試験片平行部はほぼ均一に伸びるが, 最大荷重点を過ぎると, 局所的な変形が起こり, 応力の集

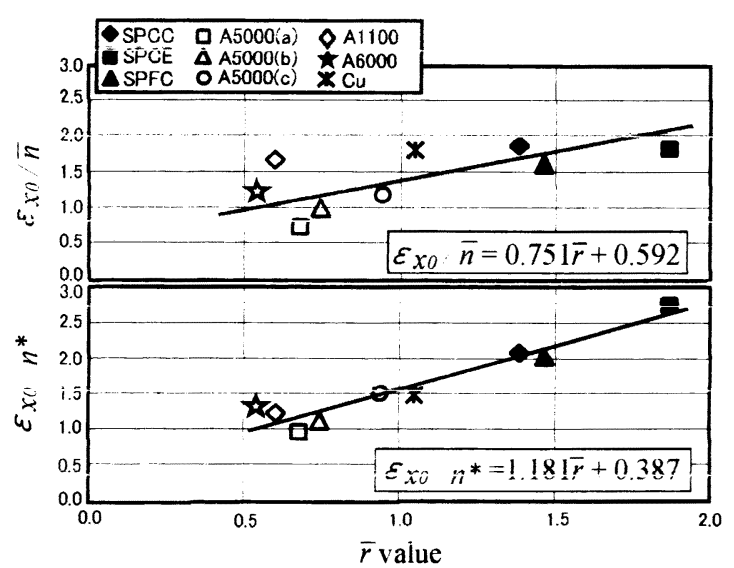

Fig. 10. Relationship between $\varepsilon_{x 0} / \bar{n}, \varepsilon_{x 0} / n^{*}$ and $\bar{r}$ value.

中によって加速度的に局所的変形が進む。応力の増加に 伴って，転位の増殖がますます進行し急激な加工硬化が起

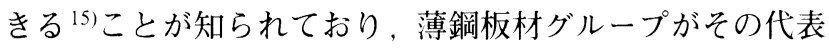
例である。一方，アルミニウム合金薄板材および銅薄板材 グループ (面心立方格子系) の材料の塑性変形を担うすべ り系が，薄鋼板材グループ（体心立方格子系）に比べて比 較的単純であり，変形が最大荷重点を超えると応力集中な どによって急激に破断に至る傾向があり，その結果局部伸 びが比較的小さい。このように両材料の塑性変形挙動の違 いが, 変形の進行に伴う $n$ 值の変化特性と密接な関係があ るものと推測される。

\section{$3 \cdot 3$ 平面ひずみ条件における成形限界ひずみ $\left(\varepsilon_{x 0}\right)$ を支配 する等価加工硬化指数 $n_{\mathrm{eq}}$ 值の決定}

FLDの予測式として，S-R理論の予測式 ${ }^{81}$ ，それを基 本として導いた後藤理論の予測式12)などがあるが，いずれ も局所くびれの発生を破断の前兆現象として捉えて近似的 にFLDを求めている。FLDを予測するときの境界条件と して, 平面ひずみ条件における限界ひずみ $\varepsilon_{x 0}$ 值が加工硬 化指数 $n$ 值に等しいと仮定し，また，等 2 軸張出し条件の 限界ひずみ值として㬰験值を用いている。各種材料に対し て, 統一的にFLDの予測值と実測值が一致する結果は, まだ得られていない(2)。また, 吉田ら ${ }^{131}$ は, S-R理論の予 測式に一致するように $n$ 值を仮定してFLDを求め, そのと きの $n$ 值を等価 $n$ 値と呼んでいる。

そこで, FLDの予測式の境界条件としての平面ひずみ条 件における FLDの $\varepsilon_{x 0}$ 值を支配している等価加工硬化指数 （以下 $n_{\mathrm{eq}}$ 值と略称）を決定することを試みた。すでにFig. 7 およびFig. 9に示したように, 実験から求められた各種 材料の FLDの $\varepsilon_{x 0}$ 值と值との間には非常に良い相関関係 が得られていることから，次のようにして $n_{\mathrm{eq}}$ 值を決定し た。すなわち, Fig.10に示すように， $\left(\varepsilon_{x 0} / \bar{n}\right)$ および $\left(\varepsilon_{x 0} / n^{*}\right)$ と部值との間の相関関係を求めると，全供試材を含めて良 い相関関係が得られた。これらの相関関係を，近似的な実 験式として式(1)および式(2)のように表すことができる。 
FLDの予測式の計算に必要な加工硬化指数の $n_{\mathrm{eq}}$ 值を, 式 (3)によって求めることができる。式(1)を用いる場合は, 式( 2)よりも推定精度が劣る。

$$
\varepsilon_{x 0} / \bar{n}=0.751 \bar{r}+0.592
$$

$\varepsilon_{x 0} / n^{*}=1.181 \bar{r}+0.387$

$$
\varepsilon_{x 0} \equiv n_{\mathrm{eq}} \equiv(1.181 \bar{r}+0.387) n^{*}
$$

\subsection{FLDの予測と実験結果との比較}

$3 \cdot 4 \cdot 1$ FLDの予測式の適合条件

$3 \cdot 1 \cdot 2$ で述べたように，平面ひずみ条件における FLD の限界ひずみ $\left(\varepsilon_{x 0}\right)$ の実測值は, 通常の $\bar{n}$ 值との間に相関関 係は得られず，むしろ $\bar{r}$ 值との相関が強く認められた。そ こで，付録に示す後藤のFLDの予測式 ${ }^{12)}$ 用い，加工硬 化指数として $n_{\mathrm{eq}}$ 值を代入してFLDの予測を行うため, 予 測式の適合条件について比較検討を行い, 次の結果が得ら れた。

(1) $r$ 值が 1 とするときの付録の式(A-2)の場合, $\varepsilon_{y} \leqq 0$ の変 形領域において実験值と良い一致が得られた。

(2) $r$ 值（塑性異方性）を考慮した付録の式(A-1)の場合， $\varepsilon_{y}>0, \varepsilon_{y}<0$ 全変形領域で実験值よりも高めの值で あった。

(3) 局所くびれ発生の角度が直角 $(\phi=\pi / 2)$ とする付録の式 $(\mathrm{A}-4)$ と式(A-5)の場合, $\varepsilon_{y} \geqq 0$ の変形領域において実験 值と良い一致が得られた。

(4) 局所くびれ発生の角度が材料によって異なる付録の式 (A-3)と式(A-5)の場合, $\varepsilon_{y} \geqq 0$ の変形領域において(3)の ケースよりもやや低めとなる結果が得られた。

したがって，FLDの予測式を変形領域によって区分し適 用することで, 比較的高精度のFLDを得られることがわ かった。すなわち, $-1 / 2 \leqq \varepsilon_{y} \leqq 00$ 変形領域に対しては ケース(1)の付録の式(A-2)を, $0 \leqq \varepsilon_{y} \leqq 1 の$ 変形領域に対して はケース(3)の付録の式(A-4)と式(A-5)を適用すれば, 実験 值とほぼ一致した実用的 FLDを求められることが明らか となった。供試材の軟鋼板 SPCCとアルミニウム合金材 A6000の例を Fig.11 に示すように, 等価加工硬化指数 $n_{\mathrm{eq}}$ 值 を使用したFLDの計算值と実験値が非常によく一致する ことを示している。

\section{$3 \cdot 4 \cdot 2$ FLDの予測精度の評価}

FLDの予測にあたり，ひずみ比を $\beta\left(=\varepsilon_{v} / \varepsilon_{x}\right)$ とするとき， $-1 / 2 \leqq \beta \leqq 0$ の変形領域に対しては付録の式(A-2), $0 \leqq \beta \leqq 1$ の変形領域に対しては付録の式(A-4)と式(A-5)を用いて，2 つの変形領域に分けて計算を行った。全ひずみ条件におけ る FLDの $\varepsilon_{x 0}$ 值の計算值と実験值との相関関係を Fig. 12 に 示すように，予測值の方が実測值よりも平均して約 $2.5 \%$ 程度高めとなっているが, 実用的には十分使用できる精度 であるといえる。予測を行うにあたっての境界条件として (a) Steel sheet SPCC

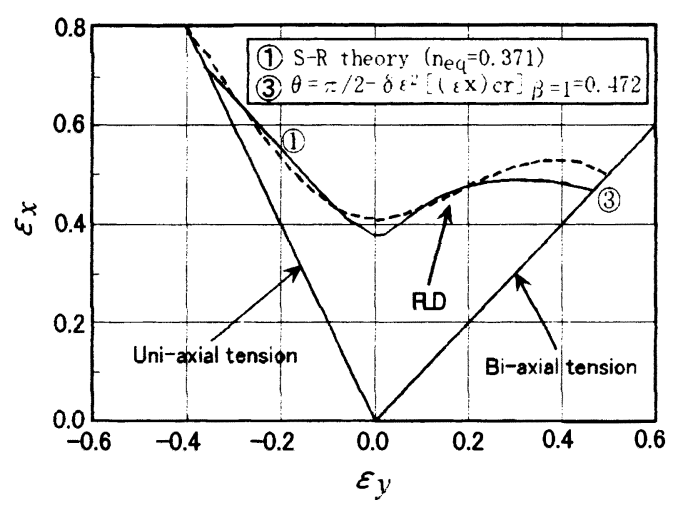

(b) $\mathrm{Al}$ alloy sheet $\mathrm{A} 6000$

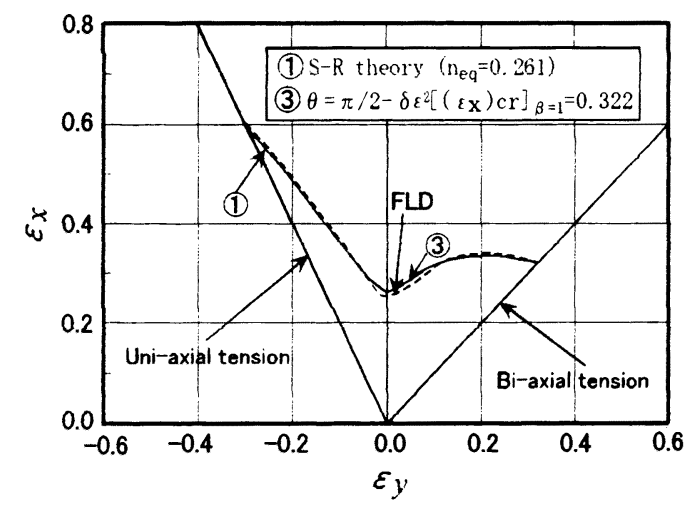

Fig. 11. Experimental FLD and calculated FLD of new modeling induced by Gotoh's theory.

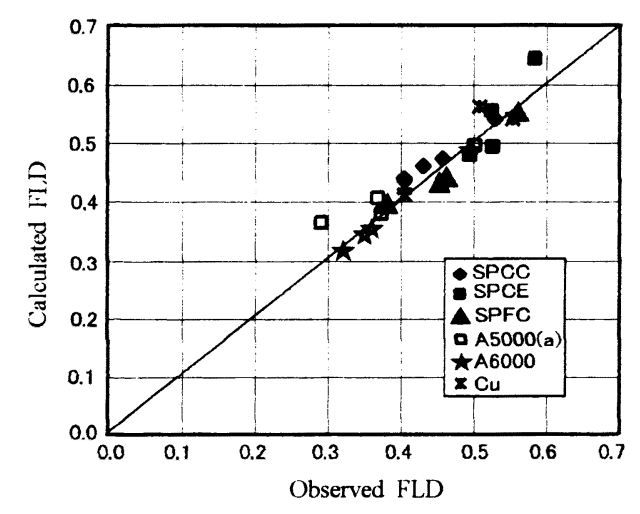

Fig. 12. Correlationship between observed FLD values and calculated FLD values of various materials.

は, 材料特性として $r$ 值, $n_{\mathrm{eq}}$ 值および等 2 軸張出し限界ひ ずみ值 $x_{1}=\left[\left(\varepsilon_{x}\right)_{\mathrm{cr}}\right]_{\beta=1}$ の 3 つの特性值が必要となる。FLDの 予測もそれほど複雑ではないことから，手間のかかる成形 限界試験をしなくても, 各種材料のFLDが得られ, 十分 実用的なFLDの予測方法といえる。

\section{4. 結言}

（1）各種の薄板材料として高張力鋼板を含めた薄鋼 板, 各種アルミニウム合金薄板および銅薄板を用いて, 等 
2軸張出し，平面ひずみ引張り，および単純1軸引張りを 含む広範な 2 軸応力条件のもとでの成形限界試験を行い， 材料別のFLDとNLDのデータベースが得られた。

(2) FLDおよびNLDにおけるそれぞれの限界ひずみ 值, とくに平面ひずみ条件の限界ひずみ $\varepsilon_{x 0}$ 值と材料特性 值（TEL, $\bar{r}$ 值， $\bar{U}$ 值）との間に良い相関関係が認められ た。

（３）引張り試験法によって, 最大荷重点を超える高ひ ずみ領域までの加工硬化指数 $n$ 值を求め, 鋼板系とアルミ 二ウム合金板や銅板系では， $n$ 值のひずみ依存性が異なっ ている。

（4） FLDの限界ひずみ $\varepsilon_{x 0}$ を支配している材料特性とし て, 最大荷重点の $n$ *值と $\bar{r}$ 值との複合特性からなる等価加 工硬化指数 $n_{\mathrm{eq}}$ の実験式を得た。

（5）局所くびれ限界理論から導いた後藤の FLD予測 式 ${ }^{12)}$ 用いて，実測FLDへの適合条件を明らかにし，変 形領域を $-1 / 2 \leqq \beta \leqq 0$ と $0 \leqq \beta \leqq 1 の 2 つ の$ 領域に分けて計算 する実用的なFLD予測式を得た。また，等価加工硬化指 数 $n_{\mathrm{eq}}$ を用いることによって実験值とよく一致することが わかった。

\section{文献}

1 ) K.Ito: 173rd Svmp. Technol. Plast., (1997), 23.

2 ) P.Keeler: Sheet Met. Ind., 48 (1971) 8, 589.

3 ) K.Nakajima, T.Kikuma and K.Hasuka: Seitetsu Kenkyu, 14 (1968), 8414

4 ) K.Tanaka, L.Gu and K.Nakajima: Proc. Jpn. Spring Conf. Technol. Plast., (1997), 31.

5 ) T.Kobayashi, K.Muraichi and H.Ishigaki: J. Jpn. Soc. Technol. Plast., 10 (1969), 793

6 ) T.Kobayashi, K.Muraichi H.Ishigaki and T.Abe: J. Jpn. Soc. Technol. Plast., 11 (1970), 495.

7 ) K.Nakajima and T.Kikuma: J. Jpn. Soc. Technol. Plast., 11 (1970), 112.

8 ) S.Stören and J.R.Rice: J. Mech. Phys. Solids, 23 (1975), 421

9 ) K.Yamakuti: J. Jpn. Soc. Technol. Plast., 27 (1986), 151

10) Z.Marciniak and K.Kuczynski: Int. J. Mech. Sci., 9 (1967), 609.

11) K.Tanaka, L.Gu, T.Suzuki and K.Nakajima: Proc. Jpn. Spring Conf. Technol. Plast., (2000), 223.

12) M.Gotoh: Trans. Jpn. Soc. Mech. Eng. (A)., 47 (1982), 92.

13) T.Yoshida, K.Ito, Y.Kuriyama and M.Usuda: J. Jpn. Soc. Technol. Plast., 38 (1997), 985.

14) R.Hill: J. Mech. Phys. Solids, 1 (1952), 19

15) 谷野 満, 鈴木 茂：鉄鋼材料の科学, 内田老鶴園, 東京, (2001), 109.
付

\section{録}

1. 板材要素に発生する局所くびれ帯の定義

$\sigma_{x}, \sigma_{x}: x, y$ 方向の作用応力

g: くびれ帯への法線単位べクトル

$\psi: x$ 方向応力に対するくびれ带の法線角度 $t$ : 板厚

2. $r$ 値（塑性異方性）を考慮したの FLDの予測式 ${ }^{12}$ $\left(\varepsilon_{x}\right)_{\mathrm{cr}}:$ 局所くびれの限界ひずみ $\sigma=F \varepsilon^{n}:$ 材料の $n$ 乗硬化則

$\alpha\left(=\sigma_{1} / \sigma_{x}\right):$ 応力比

$\beta\left(=\varepsilon_{1} / \varepsilon_{x}\right):$ ひずみ比

$\left(\varepsilon_{x}\right) \fallingdotseq \frac{(n / 2)\left\langle(2+a \beta)\{2+[(2 a-1)+(1-a) g n] \beta\}+\left\{\left(4-a^{2}\right) \beta^{2} / g n\right\}\right\rangle}{(2+\beta)\left(1+\beta+\beta^{2}\right)} \cdots(\mathrm{A}-1)$

ただし,$a=2 \bar{r} /(1+\bar{r})$

$\left(\varepsilon_{x}\right)_{\mathrm{cr}} \fallingdotseq \frac{3 \beta^{2}+n(2+\beta)^{2}}{2(2+\beta)\left(1+\beta+\beta^{2}\right)}$

ただし $, g=1, r=1$ の場合， S-R 理論 ${ }^{8}$ と一致する。

3. 局所くびれ帯の角度 $\theta$ を考慮した予測式 ${ }^{12)}$

(1) 局所くびれの角度

$\theta=\varphi-\delta \varepsilon^{2}, \quad g n \fallingdotseq \cos \theta /(1+\cos \theta)$ $(A-3)$

$\varphi=\pi / 2, \quad n=\delta \varepsilon^{2} /\left(1+\delta \varepsilon^{2}\right)$.

$(A-4)$

(2) 局所くびれの限界ひずみの予測式

$\left(\varepsilon_{x}\right)_{\mathrm{cr}}=x, \quad x^{3}-b x^{2}-c=0$.

ただし

$b=2 n /(2+\beta)$

$c=\frac{2.25 n \beta^{2}}{2 \delta(2+\beta)\left(1+\beta+\beta^{2}\right)}$

$\delta \fallingdotseq \frac{0.04167 n}{x_{1}^{3}-0.667 n x_{1}^{2}}$

$x_{1}=\left[\left(\varepsilon_{x}\right)_{\mathrm{cr}}\right]_{\beta=1}:$ 等 2 軸張出し限界ひずみ

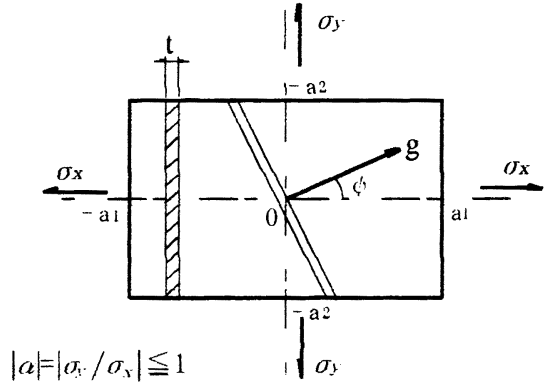

Fig. A1. Localized necking of sheet element under biaxial stress condition. 